\title{
Pioneering Modern Sculpture «An Original Relationship to the Universe»*
}

\section{Esengrini $S^{*}$ \\ Università Cattolica del Sacro Cuore (Milan), Italy}

*Corresponding author: Dr. Stefano Esengrini, Università Cattolica del Sacro Cuore (Milan), Via G.B. Morgagni, 30 I - 20129 Milan, Italy, Tel: +390229536447; Email: stefano.esengrini@ virgilio.it

\section{Conceptual Paper}

Volume 4 Issue 2

Received Date: May 10, 2021

Published Date: June 11, 2021

DOI: 10.23880/phij-16000182

America as Educator. Susan Howe

\section{Abstract}

The essay aims to analyze the work of David Smith, focusing in particular on the last three years of the American sculptor's life, in which the artist reached the pinnacle of the possibilities inscribed in his own plastic-figurative path. On the basis of an open confrontation with the vastness of the cosmos, David Smith came to play a pioneering role within the abstract art experience of the twentieth century. The monumental dimensions of his works, together with the use of stainless steel, arise from the need to establish a relationship between man and the world that has its origin in the power of the mystery of which air and light are the most emblematic witnesses.

Keywords: Sculptor's life; Air and light; Cubism; The Open

The numerous initiatives organised in Italy to celebrate the centenary of Giovanni Carandente's birth (1920-2009) allow us to deepen our knowledge of the activities promoted by this eminent scholar and to understand the nature of the work of the artists of whom he was one of the most attentive interpreters, while also contributing to our understanding of the still misunderstood phenomenon known as «abstract art» and which, after World War II, spread worldwide, with New York as its new Mecca.

If we can assume now that the difference between abstraction and figurativeness is able to say something essential about art and its mission at a cognitive level, the singular attention that Carandente reserved for that difficult, but more than ever, flourishing, language that was and continues to be sculpture, is worthy of note. Here it is spoken masterfully by those who, in the second half of the 20th century, were recognised as its most radical innovators: Alexander Calder, David Smith, Eduardo Chillida, Henry Moore, Anthony Caro.

Thus, if at first Carandente stood out as the only Italian scholar I had come across when studying Chillida, it was thanks to a conversation with François Fédier that I came

*R. W. Emerson, Essays and Lectures, Library of America, New York 1983, p. 7. \#S. Howe, The Birth-mark, New Directions, New York 1993, p. 3. 


\section{Philosophy International Journal}

to know the name of David Smith, whose work I later began to understand through the catalogue of a solo exhibition held in Milan in 1995 as a tribute to an experience that had been an epoch-making event not only in the life of art, but also in Smith's career. Sculptures in the City - this was the name of the «experiment» organised by Carandente in the streets and squares of Spoleto in 1962 - played a decisive role in the last three years of the American sculptor's life, when his extremely intense creative career was prematurely interrupted by a tragic car accident. ${ }^{1}$

The marvellous shots with which Ugo Mulas was able to immortalise Smith's sculptures set up inside the Roman Theatre of Spoleto are then only one of the first, albeit highly convincing, examples of the extraordinary "eye" with which Carandente was able to convey, some thirty years later, his understanding of what is at stake in modern sculpture by arranging with equal skill thirty-nine works by Anthony Caro in the spaces of the Trajan Markets in Rome. ${ }^{2}$ What is hidden in the silent dialogue that antiquity maintains with the challenge launched by modernity to the mere imitation of the real? $?^{3}$

\section{The Italian Legacy}

The story is well known: invited by the Italian government to create one or two monumental sculptures in one of the disused Italsider factories to be exhibited in Spoleto during the 4th Festival of the Two Worlds, David Smith managed to create an impressive series of twenty-seven iron works in the space of just one month, which were later named Voltri, after the Ligurian town where the American sculptor was able to stay and work in a singular state of grace.

It should be added that the circumstances would have made it possible to produce an even greater number of works, were it not for the fact that he ran out of time, forcing Smith to sketch out some new projects that he would complete once back in the United States. A certain amount of the precious material found in the gigantic spaces made available to him was finally sent to the Bolton Landing workshop, allowing

\footnotetext{
1 David Smith in Italy [catalogue], Charta, Milan 1995; G. Carandente, Sculture nella città. Spoleto 1962, NE Editrice, Spoleto 2007.

2 Caro at the Trajan Markets in Rome [catalogue], Lund Humphries, London 1993.

3 Incidentally, the modernity we are referring to can be traced back to the period between the beginning of the 20th century and the end of the 1960s, when sculpture underwent a further structural and conceptual metamorphosis in terms of earthworks and land-art. As Margit Rowell further observed in Qu'est-ce que la sculpture moderne? (Centre Pompidou, Paris 1986), the very expression «modern sculpture» would be pleonastic, insofar as, in the past, the term "statuary» would have been preferred to «sculpture» to identify a work in three dimensions.
}

him to produce a second series of twenty-five works emblematically entitled Voltri-Bolton, Voltron, Volton and V.B.

This apparently exhaustive account, however, would risk missing the essential point if we did not provide some further clarifications, which have the merit of putting the decisive series conceived in Italy into perspective within Smith's wider sculptural production. This series, in fact, would see, in the creation in 1961 of Cubi IX - a work in stainless steel that should have been exhibited in Spoleto - the start of what is considered by many to be the culminating moment on a plastic level of a path characterised from the outset by a constantly renewed dialogue with European abstraction inspired by Surrealism, Constructivism and, in the first place, Cubism.

In Smith's own intentions, the Italian experience was to take place under the aegis of new discoveries and new material - stainless steel - in which the artist's innermost desires would be condensed and reflected. However, the unexpected encounter with the materials found in Voltri ended up changing the sculptor's plans, and he temporarily put aside his latest achievements to give fuller voice to the figurative examples that were at the root of the research he had been carrying out since the 1940s and that aimed at making resonate the poetry contained in what have been called, from Duchamp onwards, «found objects».

The artist's lightning-fast eye was able to perceive the plastic power of what at first seemed to be nothing more than rubbish, and which, moreover, Smith himself had piled up randomly inside a sort of small open-air dump from which he was able, however, to capture the traces of a secret epiphany. In this way the Voltri and Voltri-Bolton series constitute, in their profound compositional affinity, a Proustian synthesis of the artist's past, thanks to which Smith reached one of the peaks of his production on the themes of the human figure and still life (think of Voltri XVI and XIX, followed by Volton $X X$ and V.B. XXIII).

For this reason, the two series ended up occupying a crucial role in Smith's mature production, albeit without exhausting - and this is the essential point - the fervid formal tension that led the artist to create at least six cycles of works between the end of the 1950s and the fateful 1965, the year of his death. In fact, although at the beginning of the 1960s Smith was working simultaneously on several stylistically distinct series, it was to the thrilling Cubis series that he reserved all his attention right up to the last moment, with the same prodigious superabundance that had always distinguished him creatively and that, in this case, translated into a torrent of twenty-eight variations only abruptly interrupted by fate. So, what is the decisive contribution 


\section{Philosophy International Journal}

of Cubis to the maturation of the sculptural configuration of space? And again: what is the aim of a sculpture that goes beyond the figurative to go further ahead of its own possibility?

\section{Air and light}

It has already been said: if we want to understand the historical significance of Smith's contribution to modern sculpture, we should bear in mind the series Smith worked on from the second half of the 1950s onwards and, at the same time, invite the reader to dwell on Elmer Arthur Carmean's subtle analyses developed during the retrospective that took place between 1982 and 1983 at the National Gallery of Art in Washington. ${ }^{4}$

Agricola, Sentinels, Zig[gurat]s, Circles, Voltri-Boltons, Wagons and Cubis: this is a quick sketch of the plastictheoretical developments within which theSpoleto experience is placed and which Carmean discusses meticulously. Thus, he is able to identify the underlying themes of each series themes that, to tell the truth, can be found in Smith's entire production and that, however, at least in relation to this last phase, were anticipated by a fundamental change of scale that took place around 1950, thanks to the abandonment of the relatively small dimensions in favour of a monumentality that would culminate in the three splendid stainless steel Arches (better known as Gates) of the 1960s. These are the arches - which cumulate in the Cubis themselves - that will define the access to the world in the shape of that chromaticformal background that keeps things in relation to each other and portrays them all on the same plane, indicating their coming together that compels man to face their being.

Now, while as long ago as 1965 Robert Motherwell recalled how for some years Smith had been working simultaneously on four sculptural ideas during the day ${ }^{5}-$ while at night he devoted himself to drawing nudes from life («the delicate pursuit of my life», as he liked to say) -, we must recognise that the insistence on the centrality of the human figure highlighted by so many critics (think, in particular, of Rosalind Krauss) risks distracting attention from the deeper plastic components of Smith's work. Components that are rooted in the cubist conception of space, according to which volumes are not rendered through closed forms, but through

4 E. A. Carmean, Jr. (ed.), David Smith [catalogue], National Gallery of Art, Washington 1982. Cf. H. Kramer, David Smith in Washington, «The New Criterion», Volume 1 Number 5, New York 1983, p. 62 ff.

5 Painted works in which colour plays an essential role, stainless steel structures, iron wagons with bronze wheels and heavy welded iron structures. Cf. Robert Motherwell [catalogue], Abbeville Press, New York 1983, p. 56. intersecting planes, to images of a form taking shape and being configured.

Having gained a monumental dimension, the single sculpture mimes an entering-in-presence that is not imposed by an imperious act, but possesses the same lightness as the vastness from which it comes. So if the play of the planes, as they intersect, develops horizontally or vertically in the form of a fugue whose sounds pick up and deepen the movement of the cosmos (as, for example, in the splendid Study in Arcs of 1957), all that remains is to deepen the rendering of the balance that reigns between things with the addition of light transfigured into atmosphere. Hence the use of stainless steel, polished in a sufficiently irregular manner to ensure that the rays of the surrounding world are not reflected in a mirror image on the individual sculpture, but blend chromatically in a sort of indefinite dimension that transcends distinctions to accommodate and unify all things. ${ }^{6}$

In this way we can consider ourselves exempted from having to specify the differences between the various series and, at the same time, authorised to maintain that the Cubis represent the most mature outcome of his concern to surpass the classical conception of sculpture in terms of monolithic volume. If, in fact, we aim to gain a more direct perception of the dimension from which both a plastic work (whether sculptural or pictorial) and the very possibility of our existence take shape, the use of steel will appear as the original contribution with which Smith echoes the thought already expressed by Julio González, according to whom the constitutive trait of sculpture does not lie in the traditional sculpting, but in what the Spanish artist defined as «drawing in space». So how is it possible to show and give form to air - another name for the dimension of being - as that which sustains the presence and movement of all things? What about light here, not as a direct source of irradiation, but first and foremost as atmosphere capable of defining a place?

\section{Touching with our eyes}

Examining the influence of González's work, and consequently that of Picasso and Gargallo, allows us to retrace the entire existential and artistic journey of the American sculptor, who was able to use his skills as a welder to take the idea of open sculpture to its extreme consequences, going beyond the monolithic conception of the block of marble or the casting of bronze to enclose a space through the progression of a line or the composition and articulation

6 On this basis, Hilton Kramer went so far as to compare Smith to the last Turner or the last Cézanne. Asked by John Ruskin to define his own style, Turner merely replied: «Atmosphere is my style». 


\section{Philosophy International Journal}

of planes. ${ }^{7}$

Whether the work is presented frontally (i.e. in its twodimensionality) or is properly three-dimensional, albeit not on the basis of the relationship between solids and voids, it shows that the traditional rendering of a body is not its truest representation, insofar as it merely imitates or copies what appears. On the other hand, the flatness of works such as the 1962 mini-series entitled Primo Piano in white-painted steel, or Becca and Untitled (Candida) in stainless steel from 1965, present the world in its manifest exposition, in accordance with the stillness that follows the game of retraction and opening in which things are offered in their simplicity, and also in the clarity, of what they are.

In the same way, the way the lines gravitate around a void allows them to depart from it in complete freedom and does not need to define a body through physical boundaries, preferring instead to evoke a dimension of meditation that secretly harmonizes everything through the articulated rhythm of its parts. The fact that the sculpture exerts no resistance to the gaze that penetrates it means that air can pass through it, giving it that motility which, once it has subsided, allows it to show itself in all its flagrant presence.

For this reason, rather than being touched by the dimensions of the sculptures, which make them almost architectures, the fervour that runs through and makes a sculpture, brought back to its essential structure, quiver, as does the immediacy of what comes towards us and with which we come into contact and, finally, the silent dialogue with which a spatial articulation in stainless steel does not limit itself to occupying a space, but through the light reflected in it lets the world around it stand out - this fervour, this immediacy and this dialogue, as we were saying, are all modalities of one and the same secret in whose lightness our mortal sojourn takes place. A sojourn that does not need to grasp anything, but which limits itself to brushing things with its gaze, that is, to establishing a contact and participation at a visual level that goes beyond the need to touch, which is typical of traditional volumetric sculpture.

It is now a question of understanding the origin of what David Smith was calling from 1952 «an adventure viewed», i.e. an adventure that we experience primarily on a visual level, insofar as the glimpse of the world offered by this or that sculpture sets in motion the encounter between man and reality. It is not a question, therefore, of creating a separation between man and the world, as if there were a

7 Cf. D. Smith, González: First Master of the Torch, in ID., Collected Writings, Lectures, and Interviews, University of California Press, Oakland 2018, pp. 259-264. screen between them, but of acquiring that circumspectival (as opposed to perspectival) view that allows us to grasp the world as something entire, as an integral whole. More than that: as a unity that is not reduced to the mere sum of objects, or in any case to their systematised arrangement within a space that distinguishes what is in the foreground from what is in the background, but which explains their own bursting forth and opening up by making explicit the relationships that exist between things. In fact, these things have such a lively dialogue with each other that they overlap, testifying to the importance of the fervour of the source over the rigour and necessary distancing that keeps everything under control.

It should come as no surprise, then, that Clement Greenberg conceived Smith's work as a sort of collage on a sculptural level, once again highlighting the depth of Picasso and Braques's influence, never more evident than in the twenty-eight possible variations on the theme of space as the opening up of a dimension that invites man to take part in the world that confronts him by summoning him, claiming him. In this lies the artistic and existential need that led the sculptor to arrange his works outside his studio, in the two fields that surrounded it, in order to test the outcome of his work starting from that same Openness that represented its horizon of meaning. In the same way, Smith photographed one of his decisive works - Cubi I in 1963 - from below, perhaps inspired by the famous shot with which Constantin Brancusi immortalised the ascension of his Infinite Column into the sky, widely understood as a gesture that is only possible by a being that is essentially transcendent.

\section{The Challenge of the Open}

Let's slow down and repeat with some additional nuance what has been said about the Cubis structure and the nature of the perceptions they evoke. The polished surface of steel does not merely reflect the light of the sun and the colours of the natural elements, thus exposing itself to the Open to the point of experiencing it as something unlimited. Because through the intersection and articulation of the different cubes and rectangles that make up the work, Smith was able to determine a centre of gravity that invites the beholder to gather themselves near the inner heart of the sculpture ( $\mathrm{Cubi}$ $X I, X V I I$ and $X I X)$.

This is what happens, for example, in a still life painting, which, on the one hand, owes its origin to the perception of space as a pure concession and gift and, on the other, articulates this space in terms of a relationship that the represented objects establish between themselves, determining that atmosphere or intimacy that allows the beholder to resonate with what is painted and to find shelter 


\section{Philosophy International Journal}

in it.

The movement that evokes the Open in the beholder is therefore twofold: on the one hand, the ecstasy or even the feeling of estrangement towards that which surpasses all limitation, that which from the start nullifies all pretence of control and defers to the inexhaustible; on the other, the need to match this vastness, to experience infinity not in terms of ultra-power, but as an intensity that reveals itself in the secret of recollection - as if the idea of possibility that we are accessing here safeguards more vibrantly the relationship with nothingness, which is not to be understood as a mere annihilating power, but rather as a reserve or a custodianship.

The upward movement with which the Cubis build a staircase leading from earth to sky, or the horizontal articulation of the elements that constitute them (Cubi XXIII and $X X V I$ ), or even their reflection of the world, are just alternative ways in which Smith experiences the liberating feature of the Open, of his making space, of clearing the horizon, so that from this richness a meaning can be conceived and a measure sought.

This is the destiny reserved for pioneers who, faced with a vastness that bewilders to the point of disorientation, know how to discern, beyond all reasonable hope, a landfall, a beginning, a promise. Such was the adventure conducted by Smith in his attempt to match in sculpture what had already been risked on a poetic level by James Joyce, by pushing beyond the known "without knowing how or why» (Ralph W. Emerson), driven by an enthusiasm that is at least strong enough to mitigate the pain of a loneliness that is as necessary to the creative act as it is lacerating on a strictly personal level.

«Oh David you are as delicate as Vivaldi, and as strong as a Mack truck», wrote Motherwell. ${ }^{8}$ And if such delicacy made him an adorable father and an exquisite and solicitous host, it was his intransigence towards any compromise, the generosity of his unreserved dedication to his art, his profound sense of identity that made David Smith an American, governed by an inexhaustible self-confidence and moved by a sense of defiance towards everything and everyone that placed him at the forefront of the search for truth as a man and as an artist.

Thus the new season of world art, which coincided with the arrival in America in the 1930s and 1940s of intellectuals and artists fleeing Europe and fascist bestiality, could find

8 C. Gray (ed.), David Smith by David Smith. Sculpture and Writings, Thames and Hudson, London 1988, p. 8. fertile ground in that «roaring voice» that Elio Vittorini had sensed in the very origins of American literature, so much so that he wanted to gather part of them in his Americana, an anthology soon censored by the regime's propaganda apparatus. Listen:

«Here is, continuous, the roar of hyperbole. It is a voice that roars. And it will always be this, a roaring voice, that will reveal the inward developments of man in America». ${ }^{9}$

\section{The American day}

As the frontier-place of the Open, «America» is the name we have chosen to denote the call of the boundless which man feels he must face, and to which, in his own way, Smith himself felt the need to respond, when, in the 1940s, he left New York to retire to the uncontaminated wilderness of the Adirondack Mountains, «breast to breast with the cosmos» (D. H. Lawrence). This is the reason why, in conclusion, we will linger on three writings devoted to the origin of American identity, which we take as our portals of access to a world that is mostly unknown, since it has been overshadowed by the triumph, during the 20th century, of the nefarious and illusory idea of a pax promoted in the name of maximising individual and global well-being.

It is outside the scope of this article to make a detailed analysis of these masterpieces, but we will limit ourselves to explaining a few of their important aspects, without pretending to be exhaustive. For Susan Howe's The Birthmark (1993), we need only refer to her thought couched in the form of an aphorism placed in the introduction to our essay and which picks up the title of Nietzsche's third Untimely Meditations dedicated to the figure of Schopenhauer. We ask then: in what way can America act as our educator? What does the sign-germ of its birth consist of? Where does it take its measure from?

A first, but crucial, answer to these questions can be found in a chronologically earlier work: in fact, In the American Grain (1925) by William Carlos Williams traces a genesis of America in order to grasp what runs in its veins, that is, what shapes its temperament. Here, too, we limit ourselves to a thought that clarifies what America is NOT at its core, but what it has ended up becoming because of the obsession with embodying the dream of a phantasmagorical Land of Plenty. Williams wrote about Benjamin Franklin, emblematically identified as «the greatest winner of his day»:

«He represents a voluptuousness of omnivorous energy brought to a dead stop by the rock of New World

9 E. Vittorini, Diario in pubblico, Bompiani, Milan 1999, p. 116. 


\section{Philosophy International Journal}

inopportunity. His energy never attained to a penetrant gist; rather it was stopped by and splashed upon the barrier, like a melon. His 'good' was scattered about him. This is what is called being "practical"». ${ }^{10}$

But it is to the third work that we will devote more space through some observations that have the merit of shedding light not only on the two quotations by Howe and Williams, but also on the character of David Smith himself, whom Carandente had defined as the «American Odysseus of sculpture». The work in question is the indispensable Studies in Classic American Literature (1923) by David Herbert Lawrence, of which we study chapters 1 and 12, dedicated respectively to a clarification of the «Spirit of Place» that is America and to an introduction to the figure of Walt Whitman as spiritual Captain - Lincoln's poetic alter ego - of an entire nation.

It is not enough to think of the foundation of the future United States by the Pilgrim Fathers solely on the basis of their flight from Europe, whatever the cause. Because the destruction of what is old and outdated must be accompanied, as driving the revolution, by the factor which starts the struggle. This is why Lawrence can say that «the real American day hasn't begun yet», insofar as that race of «whole men» who will have the task of establishing a new world have not yet appeared. In the words of Shakespeare's Tempest freely adapted by Lawrence:

\section{«Get a new master, be a new man»!}

Now, this is precisely the prophetic role played by Walt Whitman, who, first and like no other American writer, was able to generate a new sense of history by transforming man's stay on Earth in the name of the paths of destiny laid out to him by what the poet insistently calls the «open road». Knowing how to embark on this path, without any reward in terms of salvation, is the way in which the new man opens himself to the world, placing himself at the head of his community in the manner of a «modern American Moses».

\section{Along the way}

Beyond or, rather, on this side of meditation, of inward exploration, exaltation and ecstasy - on this side of charity, sacrifice, love and good works, «only by taking the open road does the soul come into her own». Lawrence continues:

10 W. C. Williams, In the American Grain, Albert \& Charles Boni, New York 1925, p. 153. Cf. A. Rigaud, A Phosphorous History: William Carlos Williams' In the American Grain, «European journal of American studies» [Online], 2016.
«The journey itself, down the open road. Exposed to full contact. On two slow feet. Meeting whatever comes down the open road. In company with those that drift in the same measure along the same way. Towards no goal. Always the open road». ${ }^{11}$

The celebrations of Carandente's centenary may then have reawakened - in the scientific community of universities and research and teaching institutions and, through this intermediary, in the general public - an understanding of the anticipatory reach of the research carried out by this or that creative genius, so that our being together in the world may be redesigned in the light of persevering along a common path which, by exposing us to the unknown, involves each of us in an unrepeatable way.

When asked who the artist was and how he behaved, this is how David Smith answered in 1952 :

«The artist's creative position to nature is much the same as that of primitive man.

He does not take the scientific view of all important man and view nature as "it".

$\mathrm{He}$ is the compassionate emotional man who is unquestioning,

who accepts himself as a part of nature viewing nature as "thou"»."

If this is the artist, what about the man who follows him and the open road on which they both may be walking? What will they be able to build together?

\section{Robert Henri BROTHERHOOD}

«Through art mysterious bonds of understanding and of knowledge are established among men. They are the bonds of a great Brotherhood. Those who are of the Brotherhood know each other, and time and space cannot separate them.

The Brotherhood is powerful. It has many members. They are of all places and of all times. The members do not die. One is member to the degree that he can be member, no more, no less. And that part of him that is of the Brotherhood does not die.

The work of the Brotherhood does not deal with surface events. Institutions on the world surface can rise and become powerful and they can destroy each other. Statesmen can put

11 D. H. Lawrence, Studies in Classic American Literature, Martin Secker, London 1924, p. 171.

12 D. Smith, Who is the Artist?, in ID., Collected Writings, Lectures, and Interviews, op. cit., p. 176. 
patch upon patch to make things continue to stand still. No matter what may happen on the surface the Brotherhood goes steadily on. It is the evolution of man. Let the surface destroy itself, the Brotherhood will start it again. For in all cases, no matter how strong the surface institutions become, no matter what laws may be laid down, what patches may be made, all change that is real is due to the Brotherhood.» ${ }^{13}$

13 R. Henri, The Art Spirit, Basic Books, New York 2007, pp. 15-16. 